J ournal of Bangladesh Chemical Society, Vol. 25(1), 62-70, 2012

\title{
BINUCLEAR RHENIUM AND MANGANESE CARBONYL COMPOUNDS CONTAINING HETERO-MERCAPTANES
}

MD. ANWARUL HOQUE, MD. ARZU MIAH, MD. NURUL ABSER, ABUL K. AZAD, KAMRUN N. KHAN, AND MD. MANZURUL KARIM*

Department of Chemistry, Jahangirnagar U niversity, Savar, D haka-1342, Bangladesh.

Abstract

Treatment of 2-Mercaptothiazoline, 2-Mercaptobenzimidazole, 2-Mercapto-1methylimidazole with $\left[\mathrm{M}_{2}(\mathrm{CO})_{10}\right](\mathrm{M}=\mathrm{Re}$ and $\mathrm{Mn})$ at ambient temperature in presence of decarbonylating reagent $\mathrm{Me}_{3} \mathrm{NO}$ give the complexes $\left[\mathrm{Mn}_{2}\left(\mu-\eta^{2}-\mathrm{C}_{3} \mathrm{H}_{4} \mathrm{NS}_{2}\right)_{2}(\mathrm{CO})_{6}\right](1)$, $\left[\mathrm{Re}_{2}\left(\mu-\eta^{2}-\mathrm{C}_{3} \mathrm{H}_{4} \mathrm{NS}_{2}\right)_{2}(\mathrm{CO})_{6}\right] \quad(2), \quad\left[\mathrm{Mn}_{2}\left(\mu-\eta^{2}-\mathrm{C}_{7} \mathrm{H}_{5} \mathrm{SN}_{2}\right)_{2}(\mathrm{CO})_{6}\right] \quad(3), \quad\left[\operatorname{Re}_{2}\left(\mu-\eta^{2}-\right.\right.$ $\left.\left.\mathrm{C}_{7} \mathrm{H}_{5} \mathrm{SN}_{2}\right)_{2}(\mathrm{CO})_{6}\right](4),\left[\mathrm{Re}_{2}\left(\mu-\eta^{2}-\mathrm{C}_{4} \mathrm{H}_{5} \mathrm{~N}_{2} \mathrm{~S}\right)_{2}(\mathrm{CO})_{6}\right]$ (5) and $\left[\mathrm{Re}_{2}\left(\eta^{1}-\mathrm{C}_{4} \mathrm{H}_{5} \mathrm{~N}_{2} \mathrm{SH}\right)(\mathrm{CO})_{9}\right]$ (6) respectively. All the compounds have been characterized by $\mathrm{IR},{ }^{1} \mathrm{H}$ NMR and mass spectral data. The heterocyclic ligands are expected to be coordinated to two or single metal atom through the nitrogen and sulfur atoms or via only sulfur atom.

Introduction

$\left[\mathrm{Re}_{2}(\mathrm{CO})_{10}\right]$ and $\left[\mathrm{Mn}_{2}(\mathrm{CO})_{10}\right]$ exhibit a marked propensity to react with nitrogen and sulfur containing heterocyclic compounds. ${ }^{1-7}$ Pyridine-2-thione is a special type of thioamide which acts as an ambidentate ligand with more than one coordination sites. ${ }^{8}$ It exists as a tautomeric thiol and the thione form i.e (-NH-C=S----N=C-SH) as shown in Fig 1.
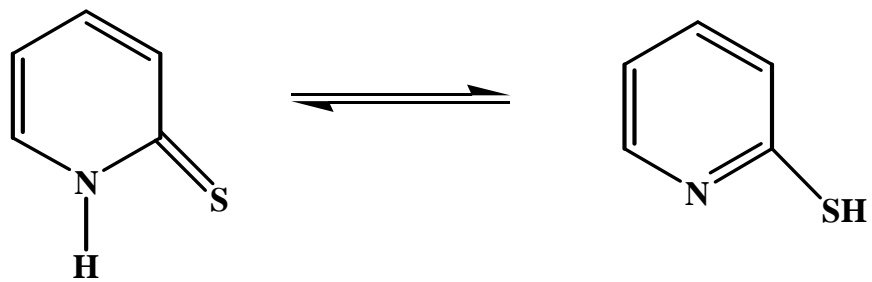

Fig. 1. Tautomeric form of pyridine-2-thione

The pyridine-2-thiolato ligand PyS is known to act as a monodentate ligand through the sulfur atom (A), ${ }^{1,8-11}$ as a bidentate chelating ligand through both the $\mathrm{N}$ and $\mathrm{S}(\mathrm{B}),{ }^{12,13}$ as a bridging ligand through $\mathrm{S}(\mathrm{C}),{ }^{14}$ as a bridging ligand through the $\mathrm{N}$ and $\mathrm{S}$ atoms linking two metal atoms (D), ${ }^{15}$ as a bridging ligand through three metal atoms (E and F) ${ }^{1,5,14,16-18}$ and joining four metal atoms through $\mathrm{N}$ and $\mathrm{S}$ atoms (G), ${ }^{6}$ (Fig. 2).

*Author for corresponding; e-mail: mkarim_ju@yahoo.com 
<smiles>[Y][SH]=c1ccccn1[TlH]</smiles>

(A)<smiles></smiles>

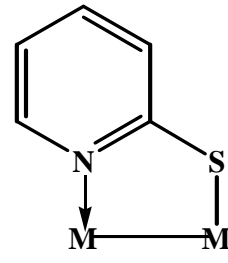

(D)

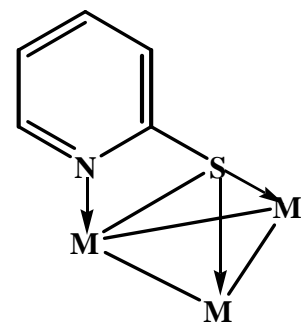

$(\mathrm{F})$<smiles></smiles>

(B)<smiles>[M]S[SH]([M])c1ccccn1</smiles>

(C)<smiles></smiles><smiles></smiles>

$(\mathrm{E})$<smiles>[Y4][n+]1ccccc1S([M])([M])[M]</smiles>

(G)

Fig. 2. Possible coordination modes of pyridine-2-thione and pyridine 2- thiolato ligand.

Pyridine-2-thione and pyrimidine-2-thione react with $\left[\mathrm{M}_{2}(\mathrm{CO})_{10}\right]$ to give $\left[\mathrm{M}_{2}\left(\mu-\eta^{2}\right.\right.$ $\left.\left.\mathrm{C}_{5} \mathrm{H}_{4} \mathrm{NS}\right)_{2}(\mathrm{CO})_{6}\right](\mathrm{M}=\mathrm{Re}, \mathrm{Mn}$ and $\mathrm{Rh})$ and $\left[\mathrm{M}_{4}\left(\mu-\eta^{3}-\mathrm{C}_{4} \mathrm{H}_{3} \mathrm{~N}_{2} \mathrm{~S}\right)(\mathrm{CO})_{12}\right](\mathrm{M}=\mathrm{Mn}, \mathrm{Re})$ in which PyS and Pymt acts as a five electron donor ligand in a $\mu_{3}$ mode ${ }^{1,17,18}$

During the last few years, we have focused on the chemistry of pyridine-2-thione, pyrimidine-2-thione, 6-methyl pyridine-2-thione, 1,2-benzenedithiol and 1,4-toluene dithiol with various transition metals. ${ }^{1,9,22}$ They have proved to be excellent ligands and afforded structurally interesting complexes. As part of our continuing synthetic effort on the reaction of heterocyclic ligands with transition metal clusters, we have set out to observe the reactions of 2-Mercaptothiazoline, 2-Mercaptobenzimidazole and 2Mercapto-1-methylimidazole with $\left[\mathrm{M}_{2}(\mathrm{CO})_{10}\right](\mathrm{M}=\mathrm{Re}$ and $\mathrm{Mn})$ and the results are described in the present paper. 


\section{Experimental}

\subsection{General Remarks}

All reactions were carried out under a dry nitrogen atmosphere. Reagent grade solvents were dried by the standard methods ${ }^{19}$ and were distilled prior to use. $\left[\mathrm{Mn}_{2}(\mathrm{CO})_{10}\right]$ and $\left[\mathrm{Re}_{2}(\mathrm{CO})_{10}\right]$ were purchased from Strem Chemical company and used as received. 2Mercaptothiazoline, 2-Mercaptobenzimidazole and 2-Mercapto-1-methylimidazole were purchased from Acros chemical company and used without further purification. Infrared spectra were recorded on a Shimadzu FTIR 8101 spectrophotometer. ${ }^{1} \mathrm{H}$ NMR spectra were recorded on a Bruker DPX 400 spectrometer; Mass spectra were recorded on a varian MAT 312 spectrometer.

\subsection{Reaction of $\left[\mathrm{M} \mathrm{n}_{2}(\mathrm{CO})_{10}\right]$ with 2-M ercaptothiazoline to form 1 .}

$\mathrm{Me}_{3} \mathrm{NO} \cdot 2 \mathrm{H}_{2} \mathrm{O}(227 \mathrm{mg}, 2.05 \mathrm{mmol})$ was added to a solution of $\left[\mathrm{Mn}_{2}(\mathrm{CO})_{10}\right](200 \mathrm{mg}$, $0.512 \mathrm{mmol})$ in $\mathrm{CH}_{2} \mathrm{Cl}_{2}(25 \mathrm{~mL})$ and stirred for 10 minutes. 2-Mercaptothiazoline (120 $\mathrm{mg}, 1.024 \mathrm{mmol}$ ) was added to the resultant solution and stirred for 48 hours at ambient temperature under nitrogen. The color of the reaction mixture changed from orange to deep orange. The solution was then passed through a short column of silica to remove excess $\mathrm{Me}_{3} \mathrm{NO}$. The solvent was removed under vacuum and the residue chromatographed by TLC $\left[\mathrm{SiO}_{2}\right.$; eluent: cyclohexane-dichloromethane $\left.(6: 4, \mathrm{v} / \mathrm{v})\right]$ to give $\left[\mathrm{Mn}_{2}\left(\mu-\eta^{2}-\mathrm{C}_{3} \mathrm{H}_{4} \mathrm{NS}_{2}\right)_{2}(\mathrm{CO})_{6}\right](1)(20 \mathrm{mg}, 28 \%)$ as orange crystals from a $\mathrm{CH}_{2} \mathrm{Cl}_{2} /$ hexane at $10^{\circ} \mathrm{C}$. IR (vCO, $\left.\mathrm{CH}_{2} \mathrm{Cl}_{2}\right) ; 2038$ vs, 2017 vs, $1919 \mathrm{br} \mathrm{cm}{ }^{-1} ;{ }^{1} \mathrm{H}$ NMR $\left(\mathrm{CDCl}_{3}\right): \delta 3.54-$ $3.60(\mathrm{ddd}, 2 \mathrm{H}, \mathrm{J}=8.0,6.0,1.5 \mathrm{~Hz}), 3.72-3.80(\mathrm{ddd}, 2 \mathrm{H}, \mathrm{J}=8.0,6.0,1.5 \mathrm{~Hz})$. MS (FAB): $\mathrm{m} / \mathrm{z}$ 514, $\left(\mathrm{M}^{+}\right), 430\left(\mathrm{M}^{+}-3 \mathrm{CO}\right), 402\left(\mathrm{M}^{+}-4 \mathrm{CO}\right), 374\left(\mathrm{M}^{+}-5 \mathrm{CO}\right), 346\left(\mathrm{M}^{+}-6 \mathrm{CO}\right)$.

2.3 Reaction of $\left[\mathrm{Re}_{2}(\mathrm{CO})_{10}\right]$ with 2-M ercaptothiazoline to form 2 .

A similar reaction to that above of $\left[\operatorname{Re}_{2}(\mathrm{CO})_{10}\right](200 \mathrm{mg}, 0.306 \mathrm{mmol})$; 2Mercaptothiazoline (73 mg, $0.612 \mathrm{mmol}$ ). and a $\mathrm{CH}_{2} \mathrm{Cl}_{2}$ solution $(25 \mathrm{~mL})$ of $\mathrm{Me}_{3} \mathrm{NO} \cdot 2 \mathrm{H}_{2} \mathrm{O}$ (136 mg, $1.22 \mathrm{mmol}$ ); followed by similar chromatographic separation afforded $\left[\operatorname{Re}_{2}\left(\mu-\eta^{2}-\mathrm{C}_{3} \mathrm{H}_{4} \mathrm{NS}_{2}\right)_{2}(\mathrm{CO})_{6}\right]$ (2) as pale yellow crystals $(40 \mathrm{mg}, 20 \%)$ from a dichloromethane and hexane mixture at $10^{\circ} \mathrm{C}$. IR $\left(\mathrm{vCO}, \mathrm{CH}_{2} \mathrm{Cl}_{2}\right) ; 2102 \mathrm{~s}, 2027 \mathrm{vs}, 1954 \mathrm{~s}$, and $1913 \mathrm{~s} \mathrm{~cm}^{-1} .{ }^{1} \mathrm{H} \mathrm{NMR}\left(\mathrm{CDCl}_{3}\right): \delta 3.54-3.60(\mathrm{ddd}, 2 \mathrm{H}, \mathrm{J}=8.0,6.0,1.5 \mathrm{~Hz}), 3.72-$ $3.78(\mathrm{ddd}, 2 \mathrm{H}, \mathrm{J}=8.0,6.0,1.5 \mathrm{~Hz})$. MS (FAB): m/z $776\left(\mathrm{M}^{+}\right), 720\left(\mathrm{M}^{+}-2 \mathrm{CO}\right), 666\left(\mathrm{M}^{+}-\right.$ $4 \mathrm{CO}), 608\left(\mathrm{M}^{+}-6 \mathrm{CO}\right)$.

\subsection{Reaction of $\left[\mathrm{M}_{2}(\mathrm{CO})_{10}\right]$ with 2-M ercaptobenzimidazole to form 3.}

A similar treatment of $\left[\mathrm{Mn}_{2}(\mathrm{CO})_{10}\right](200 \mathrm{mg}, 0.512 \mathrm{mmol})$; 2-Mercaptobenzimidazole $(154 \mathrm{mg}, 1.024 \mathrm{mmol})$; and a methanolic solution $(5 \mathrm{~mL})$ of $\mathrm{Me}_{3} \mathrm{NO} \cdot 2 \mathrm{H}_{2} \mathrm{O}(227 \mathrm{mg}$, $2.05 \mathrm{mmol}$ );

followed by removal of solvent gave a red residue. The residue was dissolved in a minimum volume of $\mathrm{CH}_{2} \mathrm{Cl}_{2}$ and chromatographed by TLC on silica gel. Elution with 
hexane/ $\mathrm{CH}_{2} \mathrm{Cl}_{2}(2: 3, \mathrm{v} / \mathrm{v})$ gave $\left[\mathrm{Mn}_{2}\left(\mu-\eta^{2}-\mathrm{C}_{7} \mathrm{H}_{5} \mathrm{~N}_{2} \mathrm{~S}\right)_{2}(\mathrm{CO})_{6}\right]$ (3) as reddish crystals (58 $\mathrm{mg}, 29 \%)$ from $\mathrm{CH}_{2} \mathrm{Cl}_{2}$ and hexane mixture at $-20^{\circ} \mathrm{C}$. IR( $\left(\mathrm{vCO}, \mathrm{CH}_{2} \mathrm{Cl}_{2}\right): 2036 \mathrm{vs}, 2017$ vs , $1922 \mathrm{br} \mathrm{cm}^{-1}$; ${ }^{1} \mathrm{H}$ NMR $\left(\mathrm{CD}_{2} \mathrm{Cl}_{2}\right): \delta 7.52(\mathrm{~d}, \mathrm{H}, \mathrm{J}=8.0 \mathrm{~Hz}), 7.25(\mathrm{~d}, \mathrm{H}, \mathrm{J}=8.0 \mathrm{~Hz}), 6.9$ $(\mathrm{dd}, \mathrm{H}, \mathrm{J}=8.0 \mathrm{~Hz}), 6.50(\mathrm{dd}, \mathrm{H}, \mathrm{J}=8.0 \mathrm{~Hz}), 8.50(\mathrm{NH}$ proton $) . \mathrm{MS}(\mathrm{FAB}): \mathrm{m} / \mathrm{z} 574$ $\left(\mathrm{M}^{+}\right), 518\left(\mathrm{M}^{+}-2 \mathrm{CO}\right), 462\left(\mathrm{M}^{+}-4 \mathrm{CO}\right)$ and $406\left(\mathrm{M}^{+}-6 \mathrm{CO}\right)$.

2.5 Reaction of $\left[\mathrm{Re}_{2}(\mathrm{CO})_{10}\right]$ with 2-M ercaptobenzimidazoleto form 4.

A similar treatment of $\left[\operatorname{Re}_{2}(\mathrm{CO})_{10}\right](400 \mathrm{mg}, 1.03 \mathrm{mmol}) ; 2$-Mercaptobenzimidazole (309 $\mathrm{mg}, 2.06 \mathrm{mmol})$; and $\mathrm{Me}_{3} \mathrm{NO} \cdot 2 \mathrm{H}_{2} \mathrm{O}(227 \mathrm{mg}, 4.12 \mathrm{mmol})$ followed by similar chromatographic separation gave $\left[\operatorname{Re}_{2}\left(\mu-\eta^{2}-\mathrm{C}_{7} \mathrm{H}_{5} \mathrm{~N}_{2} \mathrm{~S}\right)_{2}(\mathrm{CO})_{6}\right]$ (4) as pale yellow crystals (100 mg, 25\%) from $\mathrm{CH}_{2} \mathrm{Cl}_{2} /$ hexane mixture at $-20^{\circ} \mathrm{C}$. IR( $\left(v \mathrm{CO}, \mathrm{CH}_{2} \mathrm{Cl}_{2}\right): 2039 \mathrm{~s}, 2021 \mathrm{vs}$ and $1934 \mathrm{~s}(\mathrm{br}) \mathrm{cm}^{-1} .{ }^{1} \mathrm{H}$ NMR $\left(\mathrm{CD}_{2} \mathrm{Cl}_{2}\right): \delta 8.1(\mathrm{dd}, \mathrm{H}, \mathrm{J}=8.0 \mathrm{~Hz}), 7.3(\mathrm{dd}, \mathrm{H}, \mathrm{J}=8.0 \mathrm{~Hz})$, 6.01-6.6 (m, 2H), $8.5(\mathrm{NH})$. MS (FAB): m/z $835\left(\mathrm{M}^{+}\right), 782\left(\mathrm{M}^{+}-2 \mathrm{CO}\right), 754\left(\mathrm{M}^{+}-3 \mathrm{CO}\right)$, $726\left(\mathrm{M}^{+}-4 \mathrm{CO}\right), 698\left(\mathrm{M}^{+}-5 \mathrm{CO}\right), 670\left(\mathrm{M}^{+}-6 \mathrm{CO}\right)$.

2.6 Reaction of $\left[\mathrm{Re}_{2}(\mathrm{CO})_{10}\right]$ with 2-M ercapto-1-methylimidazole to form 5.

A similar treatment of $\left[\operatorname{Re}_{2}(\mathrm{CO})_{10}\right] \quad(200 \mathrm{mg}, 0.306 \mathrm{mmol})$; 2-Mercapto-1methylimidazole (697 g, $0.612 \mathrm{mmol}) ; \mathrm{Me}_{3} \mathrm{NO} \cdot 2 \mathrm{H}_{2} \mathrm{O}(136 \mathrm{mg}, 1.22 \mathrm{mmol})$; followed by similar chromatographic separation gave $\left[\mathrm{Re}_{2}\left(\mu-\eta^{2}-\mathrm{C}_{4} \mathrm{H}_{5} \mathrm{~N}_{2} \mathrm{~S}\right)_{2}(\mathrm{CO})_{6}\right]$ (5) as pale yellow crystals $(60 \mathrm{mg}, 30 \%)$ from $\mathrm{CH}_{2} \mathrm{Cl}_{2} /$ hexane mixture at $-20^{\circ} \mathrm{C}$. IR $\left(v \mathrm{CO}, \mathrm{CH}_{2} \mathrm{Cl}_{2}\right): 2037 \mathrm{~s}$, $2020 \mathrm{vs}$ and $1933 \mathrm{~s}(\mathrm{br}) \mathrm{cm}^{-1} .{ }^{1} \mathrm{H}$ NMR $\left(\mathrm{CD}_{2} \mathrm{Cl}_{2}\right): \delta 3.60$ (s, $3 \mathrm{H}$, methyl protons), $6.65(\mathrm{~d}$, $\mathrm{H}, \mathrm{J}=8.0 \mathrm{~Hz})$ and $6.88(\mathrm{~d}, \mathrm{H}, \mathrm{J}=8.0 \mathrm{~Hz})$. MS (FAB): $\mathrm{m} / \mathrm{z} 766\left(\mathrm{M}^{+}\right), 710\left(\mathrm{M}^{+}-2 \mathrm{CO}\right), 682$ $\left(\mathrm{M}^{+}-3 \mathrm{CO}\right), 654\left(\mathrm{M}^{+}-4 \mathrm{CO}\right), 626\left(\mathrm{M}^{+}-5 \mathrm{CO}\right), 598\left(\mathrm{M}^{+}-6 \mathrm{CO}\right)$.

2.7 Reaction of $\left[\mathrm{Re}_{2}(\mathrm{CO})_{10}\right]$ with an excess of 2-M ercapto-1-methylimidazole to form 6 .

A similar reaction of $\left[\operatorname{Re}_{2}(\mathrm{CO})_{10}\right]$ (200 mg, $\left.0.306 \mathrm{mmol}\right) ; 2$-Mercapto-1-methylimidazole (139 mg, $1.24 \mathrm{mmol}) ; \mathrm{Me}_{3} \mathrm{NO} \cdot 2 \mathrm{H}_{2} \mathrm{O}(136 \mathrm{mg}, 1.22 \mathrm{mmol})$; followed by similar chromatographic separation gave $\left[\mathrm{Re}_{2}\left(\eta^{1}-\mathrm{C}_{4} \mathrm{H}_{5} \mathrm{~N}_{2} \mathrm{SH}\right)(\mathrm{CO})_{9}\right] 6$ as pale yellow crystals $(80 \mathrm{mg}, 37 \%)$ from $\mathrm{CH}_{2} \mathrm{Cl}_{2}$ /hexane at $-20^{\circ} \mathrm{C}$. IR $\left(\mathrm{vCO}, \mathrm{CH}_{2} \mathrm{Cl}_{2}\right): 2098 \mathrm{vs}, 2030 \mathrm{~s}$ and $1965 \mathrm{~s}$ (br) $1921 \mathrm{~s}$ and $1994 \mathrm{~s} \mathrm{~cm}^{-1} .{ }^{1} \mathrm{H}$ NMR $\left(\mathrm{CDCl}_{3}\right): \delta 3.69$ (s, 3H, methyl protons), 6.82 $(\mathrm{d}, \mathrm{H}, \mathrm{J}=20.0 \mathrm{~Hz}), 6.93(\mathrm{~d}, \mathrm{H}, \mathrm{J}=20.0 \mathrm{~Hz}), 12.63(\mathrm{NH}), \mathrm{MS}(\mathrm{FAB}): \mathrm{m} / \mathrm{z} 738\left(\mathrm{M}^{+}\right)$.

Results and Discussion

Treatment of $\left[\mathrm{M}_{2}(\mathrm{CO})_{10}\right](\mathrm{M}=\mathrm{Mn}$ and $\mathrm{Re})$ with 2-Mercaptothiazoline in presence of decarbonylating reagent $\mathrm{Me}_{3} \mathrm{NO} \cdot 2 \mathrm{H}_{2} \mathrm{O}$ in $\mathrm{CH}_{2} \mathrm{Cl}_{2}$ for 48 hours at ambient temperature followed by chromatographic separation and usual work-up resulted in the isolation of $\left[\mathrm{Mn}_{2}\left(\mu-\eta^{2}-\mathrm{C}_{3} \mathrm{H}_{4} \mathrm{NS}_{2}\right)_{2}(\mathrm{CO})_{6}\right] \quad(1) \quad(28 \%)$ and $\left[\mathrm{Re}_{2}\left(\mu-\eta^{2}-\mathrm{C}_{3} \mathrm{H}_{4} \mathrm{NS}_{2}\right)_{2}(\mathrm{CO})_{6}\right]$ (2) (20\%) respectively (Scheme 1). Compounds 1 and 2 have been characterized by IR, ${ }^{1} \mathrm{H}$ NMR and mass spectral data. 


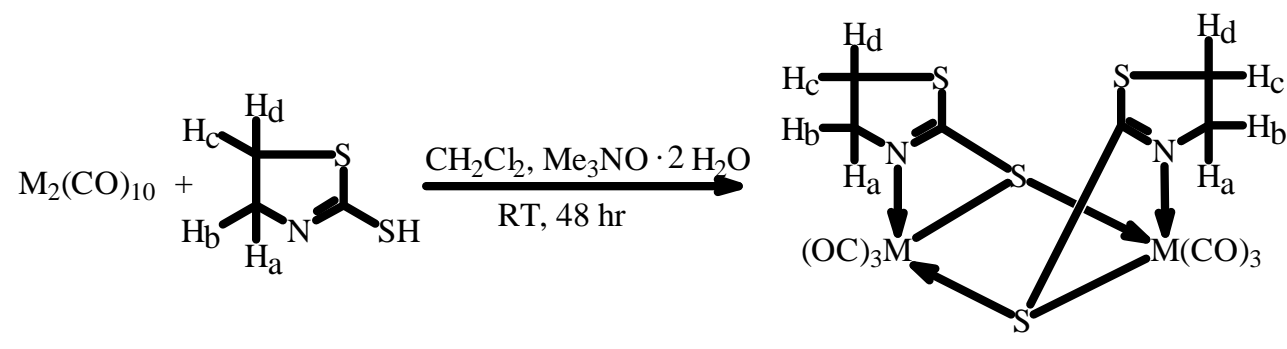

$1 ; M=M n, 2 ; M=R e$

Scheme 1.

The infrared spectra of 1 and 2 in the carbonyl stretching region exhibit $v(\mathrm{CO})$ bands in the range $2102-1913 \mathrm{~cm}^{-1}$, indicating that all of the carbonyl groups are terminal, each metal atom carries three terminal carbonyl groups. The spectral pattern are very similar to that reported for $\left[\operatorname{Re}_{2}\left(\mu-\eta^{2}-\mathrm{C}_{5} \mathrm{H}_{4} \mathrm{NS}\right)_{2}(\mathrm{CO})_{6}\right]{ }^{1}$ indicating that they have very similar structures having a dinuclear, cis-tricarbonyl arrangement.

The ${ }^{1} \mathrm{H}$ NMR spectrum of 1 in $\mathrm{CDCl}_{3}$ exhibits two sets of multiplet at $\delta 3.54-3.60$ and 3.72-3.80 assignable to the methylene protons of thiazolato ligand as indicated by the sets $\left(\mathrm{H}_{\mathrm{c}}\right.$ and $\left.\mathrm{H}_{\mathrm{d}}\right)$ and $\left(\mathrm{H}_{\mathrm{a}}\right.$ and $\left.\mathrm{H}_{\mathrm{b}}\right)$ respectively due to their diastereotopic nature. It is speculated that the $\mathrm{H}_{\mathrm{a}}$ and $\mathrm{H}_{\mathrm{b}}$ resonate at lower field than that of $\mathrm{H}_{\mathrm{c}}$ and $\mathrm{H}_{\mathrm{d}}$ due to the electron withdrawing effect of both $\mathrm{N}$ and $\mathrm{S}$ atoms in thiazole ring. Compound 2 shows the similar sets of multiplet at $\delta 3.54-3.60$ and $3.72-3.78$ in the ${ }^{1} \mathrm{H}$ NMR spectrum assignable for the methylene protons of thiazolato ligand (See Scheme 1). The mass spectra of compounds 1 and 2 exhibit molecular ion peaks at m/z 514 and 776 respectively and fragmentation peaks due to the successive loss of six carbonyl ligands.

Unfortunately, we were unable to grow X-ray quality crystals of 1 and 2. However on the basis of spectral evidences, it may be anticipated that each thiazolato ligand coordinates to one metal center to form a four membered chelate ring. As a whole, compounds 1 and 2 are binuclear metal complexes with three fused four membered rings having ancillary six CO ligands. The coordination geometry around the metal atom is probably octahedral.

A similar reaction of $\left[\mathrm{M}_{2}(\mathrm{CO})_{10}\right](\mathrm{M}=\mathrm{Mn}$ and $\mathrm{Re})$ with 2-Mercaptobenzimidazole gave the compounds $\left[\mathrm{Mn}_{2}\left(\mu-\eta^{2}-\mathrm{C}_{7} \mathrm{H}_{5} \mathrm{SN}_{2}\right)_{2}(\mathrm{CO})_{6}\right]$ (3) (29\%) and $\left[\mathrm{Re}_{2}\left(\mu-\eta^{2}-\mathrm{C}_{7} \mathrm{H}_{5} \mathrm{SN}_{2}\right)_{2}(\mathrm{CO})_{6}\right]$ (4) $(23 \%)$ respectively (Scheme 2 ), both have been characterized by IR, ${ }^{1} \mathrm{H}$ NMR and mass spectral data.

The $v(\mathrm{CO})$ stretching frequencies of 3 and 4 lie in the range $2039-1922 \mathrm{~cm}^{-1}$, indicating that all the carbonyl groups are terminal, having the same pattern of spectrum to that reported for $\left[\operatorname{Re}_{2}\left(\mu-\eta^{2}-\mathrm{C}_{5} \mathrm{H}_{4} \mathrm{NS}\right)_{2}(\mathrm{CO})_{6}\right]^{1}$, showing the structural similarity with a dinuclear, cis-tricarbonyl arrangement. The ${ }^{1} \mathrm{H}$ NMR spectrum of 3 contains three sets of signal. Among them, two doublets at $\delta 7.52(\mathrm{~J}=8.0 \mathrm{~Hz})$ and $7.25(\mathrm{~J}=8.0 \mathrm{~Hz})$ 
assignable for protons $\mathrm{H}_{\mathrm{d}}$ and $\mathrm{H}_{\mathrm{a}}$ respectively. The two doublets of doublet at $\delta 6.5\left(\mathrm{~J}_{\mathrm{Ha}-\mathrm{H}}\right.$ $\left.=\mathrm{J}_{\mathrm{Hb}-\mathrm{Hc}}=\mathrm{J}=8.0 \mathrm{~Hz}\right)$ and $6.9\left(\mathrm{~J}_{\mathrm{Hb}-\mathrm{Hc}}=\mathrm{J}_{\mathrm{HC}-\mathrm{Hd}}=\mathrm{J}=8.0 \mathrm{~Hz}\right)$ accounts for the $\mathrm{H}_{\mathrm{a}}$ and $\mathrm{H}_{\mathrm{d}}$ respectively, while the relatively downfield signal at $\delta 8.5$ has been assigned for the imine $(=\mathrm{N}-\mathrm{H})$ proton of 2-mercaptobenzimidazole ligand. Very unusual, a different three sets of signals are observed for the ${ }^{1} \mathrm{H}$ NMR spectrum of Re analog 4 at $\delta 8.1(\mathrm{~J}=8.0 \mathrm{~Hz})$, $7.3(\mathrm{~J}=8.0 \mathrm{~Hz}), 6.01-6.6$ and $8.5(\mathrm{NH})$. The two doublets of doublet at $\delta 7.3$ and 8.1 are due to the $\mathrm{H}_{\mathrm{a}}$ and $\mathrm{H}_{\mathrm{d}}$ respectively while the multipletes at $\delta$ 6.01-6.6 is attributable to $\mathrm{H}_{\mathrm{b}}$ and $\mathrm{H}_{\mathrm{c}}$. The siglet at $\delta 8.5$ has been assigned for the imine $(=\mathrm{N}-\mathrm{H})$ proton of 2mercaptobenzimidazole ligand. A slight difference in NMR spectrum for Mn and Re analogs is presumably due to the instinct nature of the metal atom. The coupling constants for 4 are in good agreement with those found for $\left[\operatorname{Re}_{2}\left(\mu-\eta^{2}-\mathrm{C}_{5} \mathrm{H}_{4} \mathrm{NS}\right)_{2}(\mathrm{CO})_{6}\right]^{1}$ and $\left[\mathrm{Mn}_{2}\left(\mu-\eta^{2}-\mathrm{C}_{5} \mathrm{H}_{4} \mathrm{NS}\right)_{2}(\mathrm{CO})_{6}\right] .{ }^{20}$

The FAB mass spectra of compounds 3 and 4 exhibit molecular ion peaks at $\mathrm{m} / \mathrm{z} 574$ and 835 respectively and fragmentation peaks due to the successive loss of six carbonyl ligands. From the forgoing spectral evidences it is evident that both the compounds are isostructural having 2-mercaptobenzimidazolato ligand bridges two metal centers through the sulfur atom and the nitrogen atom coordinates to one manganese/rhenium center to form a four membered chelate ring. Thus the compound 3 and 4 are dinuclear compounds with three fused four membered rings and ancillary six $\mathrm{CO}$ ligands. The coordination geometry around the metal atom is assumed to be octahedral with distortions resulting from the small ligand bite angle. Each molecule contains two $\mathrm{NH}$ protons. The compounds are proposed to be noncentrosymmetric with a boat conformation.
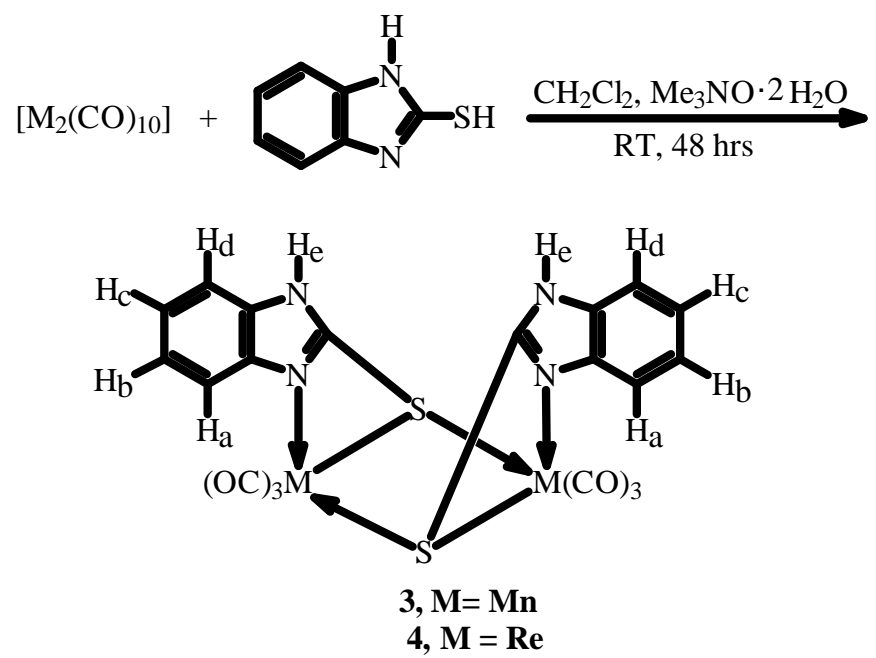

Scheme 2. 
Compound $\left[\mathrm{Re}_{2}\left(\mu-\eta^{2}-\mathrm{C}_{4} \mathrm{H}_{5} \mathrm{~N}_{2} \mathrm{~S}\right)_{2}(\mathrm{CO})_{6}\right]$ (5) (30\%) was obtained by the reaction of $\left[\mathrm{Re}_{2}(\mathrm{CO})_{10}\right]$ with 2-Mercapto-1-methyl imidazole in presence of $\mathrm{Me}_{3} \mathrm{NO} \cdot 2 \mathrm{H}_{2} \mathrm{O}$ in $\mathrm{CH}_{2} \mathrm{Cl}_{2}$ for 48 hours at ambient temperature. It has been characterized by IR, ${ }^{1} \mathrm{HNMR}$ and mass spectral data. The $v(C O)$ spectrum of 5 shows $v(C O)$ absorption bands at 2037s, 2020vs and $1933 \mathrm{~s}(\mathrm{br}) \mathrm{cm}^{-1}$ indicating that all the carbonyl groups are terminal. This spectral pattern is characteristic of a dinuclear cis-tricarbonyl arrangement ${ }^{1}$ and supports a noncentro-symmetric structure.

The ${ }^{1} \mathrm{H}$ NMR spectrum of 5 in $\mathrm{CD}_{2} \mathrm{Cl}_{2}$ shows three well separated resonances at $\delta 3.60$, 6.65 and 6.88 due to one methyl group and two equivalent imidazolato rings respectively. The mass spectrum of compound 5 shows the molecular ion peak at $\mathrm{m} / \mathrm{z} 766$ which fully agrees with the formula of the compound. This rules out the cubane type of structure with non-coordinated nitrogen atoms as in $\left[\mathrm{Re}_{4}\left(\mathrm{SiMe}_{4}\right)_{4}(\mathrm{CO})_{12}\right]^{21}$ The 2-mercapto-1methyl imidazolato ligand acts as a five electron donor with chelating and bridging groups and the resulting compound complies with the 18 electron formalism. The above statement and spectral evidences support the molecular formula $\left[\operatorname{Re}_{2}\left(\mu-\eta^{2}-\right.\right.$ $\left.\left.\mathrm{C}_{4} \mathrm{H}_{5} \mathrm{~N}_{2} \mathrm{~S}\right)_{2}(\mathrm{CO})_{6}\right]$ and the proposed structure for the complex 5 is shown in Scheme 3.

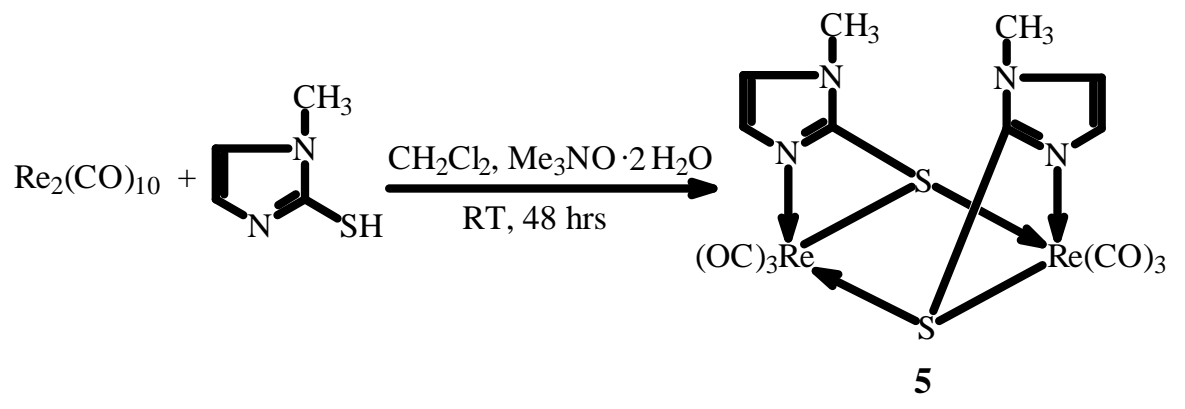

Scheme 3.

Treatment of $\left[\operatorname{Re}_{2}(\mathrm{CO})_{10}\right]$ with an excess of 2-Mercapto-1-methyl imidazole at room temperature in presence of $\mathrm{Me}_{3} \mathrm{NO} \cdot 2 \mathrm{H}_{2} \mathrm{O}$ leads to a novel $\eta$-type compound $\left[\operatorname{Re}_{2}\left(\eta^{1}\right.\right.$ $\left.\left.\mathrm{C}_{4} \mathrm{H}_{5} \mathrm{~N}_{2} \mathrm{SH}\right)(\mathrm{CO})_{9}\right](6)$ (Scheme 4 ) in $37 \%$ yield. 


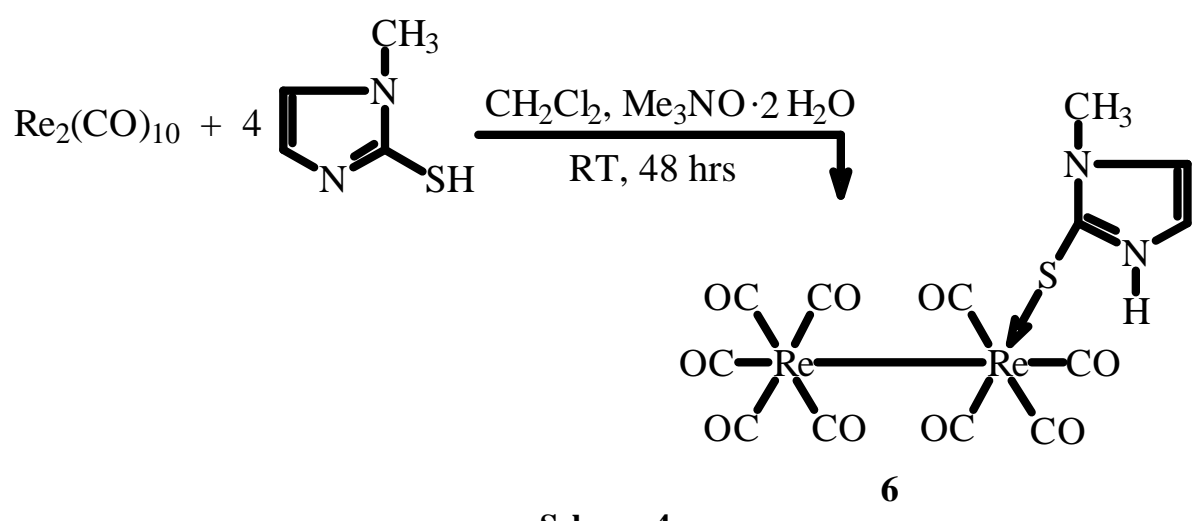

Scheme 4

The compound 6 has been characterized by IR, ${ }^{1} \mathrm{HNMR}$ and mass spectral data. The $v$ (CO) spectrum shows absorption bands at 2098vs, 2030s, $1965 \mathrm{~s}(\mathrm{br}), 1921 \mathrm{~s}$ and 1994s $\mathrm{cm}^{-1}$. This spectral pattern is the characteristic of a M-(CO) $)_{9}$ arrangement. ${ }^{5}$ The ${ }^{1} \mathrm{H}$ NMR spectrum of 6 in $\mathrm{CDCl}_{3}$ shows resonances at $\delta 3.69,6.82,6.93$ and a broad signal at $\delta$ 12.63. The down field signal at $\delta 3.69$ is due to the protons of $\mathrm{CH}_{3}$ which is attached to the $\mathrm{N}$ atom of imidazolato ligand. A broad signal at $\delta 12.63$ accounts for the presence of the imine $(=\mathrm{N}-\mathrm{H})$ proton in 2-mercapto 1-methyl imidazole ligand.

The mass spectrum of 6 shows the molecular ion peak at $\mathrm{m} / \mathrm{z} 738$ which agrees with the proposed formula. The 2-Mercapto-1-methyl imidazolato moiety acts as a two electron donor ligand by forming a $\eta$ type bonding via $\mathrm{S}$ atom to one of the Re atoms. Compound 6 is a dinuclear rhenium with axial and equatorial $\mathrm{CO}$ ligands. The coordination geometry around each Re atom is supposed to be octahedral with little distortion due to the small ligand bite. Electron counting shows that the compound is electron precise and follows the 18-electron rule formalism.

\section{Acknowledgement}

The authors acknowledge Prof. H. G. Alt of University of Bayreuth, Germany for mass spectral data and Jahangirnagar University for financial support.

\section{Refer ences}

1. A. J. Deeming, M. Karim, P.A. Bates and M.B. Hursthouse, Polyhedron, 1988, 7, 1401.

2. A. J. Deeming, M. M. Karim, N. I. Powell and K. I. Hardcastle, Polyhedron, 1990, 9, 623.

3. A. J. Deeming and M. Karim, Polyhedron, 1991, 10, 837.

4. B. C. Cockerton, A. J. Deeming, M. M. Karim, and K. I. Hardcastle, J. Chem. Soc., Dalton Trans., 1991, 431. 
5. K. I. Hardcastle, B. C. Cockerton, A. J. Deeming, and M. Karim, J. Chem. Soc., Dalton Trans., 1992, 1607.

6. A. J. Deeming, K. I. Hardcastle and M. Karim, Inorg. Chem., 1992, 31, 4792.

7. M. Karim, K. Kundu, and S. M. Bashirullah, Indian J . Chem., 1995, 34A, 918.

8. A. J. Deeming, M. N. Meah, M. H. Dawes, and M. B. Hursthouse, J. Organomet. Chem., 1986, 229, C25.

9. A. J. Deeming, M. N. Meah, Inorg. Chim. Acta, 1986, 117, L13.

10. C. Lecomte, St. Skoulia, P. Aslanidis, P. Karagiannidis, and St. Papastefanou, Polyhedron, 1989, 8, 1103.

11. D. M. L. Goodgame, A. M. Z. Slawin, D. J. Williams and P. W. Zard, Inorg. Chim. Acta, 1988, $148,5$.

12. J. Abbot, D. M. L. Goodgame, and I. Jeeves, J. Chem. SoC., D alton Trans. 1978, 880.

13. F.A. Cotton, and W. H. Isley, Inorg. Chim. Acta, 1982, 59, 231.

14. Y. K. Au, K. K. Cheung, and W. T. Wong, Inorg. Chim. Acta, 1995, 228, 267.

15. D. M. L. Goodgame, R. W. Rollins, and A.C. Skapski, Inorg. Chim. Acta, 1984, 83, 11.

16. R. Castro, M. L. Duran, J. A. Gracia-Vazquez, J. Romero, A. Sousa, E. E. Castellano, and J. Zukerman-Schpector, J. Chem. Soc., D alton Trans. 1988, 235.

17. A. J. Deeming, M. N. Meah, P. A. Bates and M. B. Hursthouse, J. Chem Soc. Dalton Trans. 1988, 235.

18. L. A. Oro, M. A. Ciriano, F. Vigur, A. Tripichio, M. Tripicchio Camellini, and F. J. Lahoz, Nouv. J. Chem., 1986, 10, 75.

19. B. S. Furniss, A. J. Hannaford, P. W. G. Smith and A. R. Tatchell, "Vogel's Practical Organic Chemistry", (5 ${ }^{\text {th }}$ edition), Longman Scientific Technical, John Wiley and Sons, 1989.

20. S. E. Kabir, M. M. Karim, K. Kundu, S. M. Bashir Ullah, and K. I. Hardcastle, J O Organomet. Chem., 1996, 517, 155.

21. W. Harrison, W. C. Marsh, and J. totter, J . Chem, Soc., D alton. Trans., 1972, 1009.

22. M. M. Karim, M. N. Abser, and Nasreen Sultana, J. Bangladesh Chem. Soc., 2006, 19, 20.

(Received : 16 N ovember, 2011; Accepted : 2 A pril, 2012) 


\section{Graphical A bstract}

\section{Binuclear Rhenium and Manganese Carbonyl Compounds Containing Hetero-mercaptanes}

Anwarul Hoque, Md. Arzu Miah, Md. Nurul Abser, Abul Khair Azad, Kamrun

Nahar Khan, and Md. Manzurul Karim*

D epartment of Chemistry, J ahangirnagar U niversity, Savar, D haka-1342,

Bangladesh.

Email: mkarim_ju@yahoo.com

A series of binuclear complexes $\left[\mathrm{Mn}_{2}\left(\mu-\eta^{2}-\mathrm{C}_{3} \mathrm{H}_{4} \mathrm{NS}_{2}\right)_{2}(\mathrm{CO})_{6}\right](1), \quad\left[\operatorname{Re}_{2}\left(\mu-\eta^{2}-\right.\right.$ $\left.\left.\mathrm{C}_{3} \mathrm{H}_{4} \mathrm{NS}_{2}\right)_{2}(\mathrm{CO})_{6}\right] \quad(2), \quad\left[\mathrm{Mn}_{2}\left(\mu-\eta^{2}-\mathrm{C}_{7} \mathrm{H}_{5} \mathrm{SN}_{2}\right)_{2}(\mathrm{CO})_{6}\right] \quad(3), \quad\left[\operatorname{Re}_{2}\left(\mu-\eta^{2}-\right.\right.$ $\left.\left.\mathrm{C}_{7} \mathrm{H}_{5} \mathrm{SN}_{2}\right)_{2}(\mathrm{CO})_{6}\right] \quad(4), \quad\left[\operatorname{Re}_{2}\left(\mu-\eta^{2}-\mathrm{C}_{4} \mathrm{H}_{5} \mathrm{~N}_{2} \mathrm{~S}\right)_{2}(\mathrm{CO})_{6}\right] \quad$ (5) and $\left[\operatorname{Re}_{2}\left(\eta^{1}-\right.\right.$ $\left.\mathrm{C}_{4} \mathrm{H}_{5} \mathrm{~N}_{2} \mathrm{SH}\right)(\mathrm{CO})_{9}$ ] (6) were synthesized and characterized by the reaction of $\mathrm{M}_{2}(\mathrm{CO})_{10}(\mathrm{M}=\mathrm{Re}$ and $\mathrm{Mn}$ ) with varying amount of different heterocylic mercaptane ligands in presence of decarbonylating reagent $\mathrm{Me}_{3} \mathrm{NO}$.

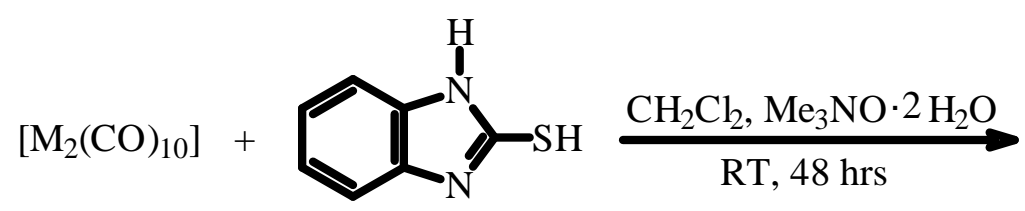

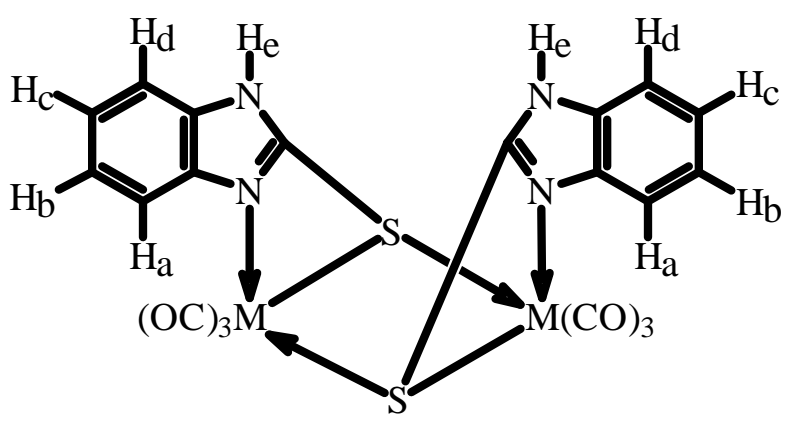

